\title{
Host Species-Dependent Transmission of Tomato Leaf Curl New Delhi Virus-ES by Bemisia tabaci
}

\author{
Dirk Janssen *(D), Almudena Simón, Maher Boulares and Leticia Ruiz (D) \\ Centro La Mojonera, IFAPA, 04745 La Mojonera, Spain; almudenasimonmartinez@gmail.com (A.S.); \\ maher.boularesbae@gmail.com (M.B.); mleticia.ruiz@juntadeandalucia.es (L.R.) \\ * Correspondence: dirk.janssen@juntadeandalucia.es
}

check for updates

Citation: Janssen, D.; Simón, A.; Boulares, M.; Ruiz, L. Host Species-Dependent Transmission of Tomato Leaf Curl New Delhi Virus-ES by Bemisia tabaci. Plants 2022, 11, 390. https://doi.org/ $10.3390 /$ plants 11030390

Academic Editor: Francisco Tenllado

Received: 12 January 2022

Accepted: 28 January 2022

Published: 30 January 2022

Publisher's Note: MDPI stays neutral with regard to jurisdictional claims in published maps and institutional affiliations.

Copyright: (C) 2022 by the authors. Licensee MDPI, Basel, Switzerland. This article is an open access article distributed under the terms and conditions of the Creative Commons Attribution (CC BY) license (https:// creativecommons.org/licenses/by/ $4.0 /)$.

\begin{abstract}
The tomato leaf curl New Delhi virus (ToLCNDV) is a bipartite, single-stranded begomovirus that was first identified in India in 1995 affecting solanaceous crops. A different strain, named ToLCNDV-ES, was introduced in Spain in 2012 and causes severe symptoms in zucchini crops. Virus transmission experiments with the whitefly Bemisia tabaci, were used to compare the transmission parameters in zucchini and tomato plants. The minimum acquisition access period and inoculation access period of ToLCNDV-ES transmission was similar in zucchini and tomato. However, the transmission efficiency was significantly higher in zucchini (96\%) compared to tomato $(2 \%)$. The maximum retention of the virus in the vector was 16 days. B. tabaci feeding on, or recently emerged from infected zucchini plants, accumulated more virus than those from infected tomato, as determined by real-time PCR. A total of $20 \%$ of $B$. tabaci that were recently emerged from infected zucchini, and none from infected tomato, were able to transmit the virus to virus-free zucchini. The results may explain the different incidences of ToLCNDV-ES in zucchini and tomato crops in Spain. But they are also relevant for ToLCNDV-ES management of crops and the role of the trade and transport of infected plant material, when small-sized immature stages of $B$. tabaci could be a source of infection.
\end{abstract}

Keywords: begomovirus; Bemisia tabaci; crop protection; zucchini; tomato

\section{Introduction}

The tomato leaf curl New Delhi virus (ToLCNDV) is a bipartite, single-stranded DNA begomovirus (genus Begomovirus, familiy Geminiviridae) that was first identified in India in 1995 affecting solanaceous crops [1] and thereafter causing major damage to cucurbit crops on the Indian subcontinent [2]. ToLCNDV was first detected in Europe in 2012, affecting zucchini squash, melon, and to a lesser degree tomato, in Spain [3,4]. Subsequently the virus was reported from Estonia, Greece, Italy, Portugal, Spain, Tunisia, Morocco, and Algeria [5]. The latest studies of ToLCNDV from Spanish isolates provide evidence that it is a new strain, denominated ToLCNDV-ES, that may have evolved by recombination [6,7]. Since the apparent speed by which ToLCNDV spreads to different countries and the extent of several outbreaks in countries such as Spain and Italy [8,9], the virus is listed as a quarantine pest by EPPO [5]. Symptoms that are produced by ToLCNDV-ES in zucchini are curling, chlorosis and vein thickening of leaves, stunted growth, and fruit deformation and abortion, whereas in tomato the symptoms in leaves are reminiscent of tomato yellow leaf curl disease [6]. ToLCNDV-ES genome titres that are detected are significantly lower in tomato than in zucchini plants, which may be related to the dissimilarities in symptom expression, capability of detection, and transmission of the virus [10]. Although ToLCNDV transmission through seeds and mechanical transmission have been experimentally shown to be possible, they are expected to be of minor significance under field conditions [11]. Instead, ToLCNDV-ES is reported to be transmitted by Mediterranean-Q1 Bemisia tabaci cryptic species in Spain, and probably by the Med-Q2 species in Italy [12,13]. 
The Mediterranean country of Spain has over 55,000 ha of tomato, 18,000 ha of muskmelon, and 11,000 ha of zucchini (data from 2020 from https: / / www.mapa.gob.es). Significant portions of these crop surfaces are very near to one another and are located within the same regions such as the south-east of Spain, where ToLCNDV-ES and its vector, B. tabaci cryptic species Q1 are highly adapted [12]. The presence of a potentially broad host range within the same geographic region jeopardizes economically important crops in the region [14] and could make the control of plant viruses difficult. B. tabaci-transmission of ToLCNDV-ES between tomato and zucchini has been reported [6], but details on the major parameters of the transmission and unknown. Viruses that belong to member species of the genus Begomovirus are considered as being transmitted in a non-propagative, persistent, circulative manner by the whitefly $B$. tabaci. Circulative, non-propagative viruses do not replicate in vector tissues, but traverse the insect gut, hemolymph, and salivary tissue membranes to reach the salivary glands for transmission [15]. Following acquisition, virions from many begomovirus species can be detected often in the whitefly vector for its entire life [16], yet the efficiency of transmission decreases with an increase in whitefly age and is negatively correlated with the amount of virus that is detectable in the vector.

Differences in the transmission of ToLCNDV-ES between different host species could yield epidemiological knowledge that could predict the success of control measures within multicrop horticulture regions. This also refers to the management of infected residues where plants that are removed from greenhouses after the crop harvest has finished that are often loaded with B. tabaci immature stages. Traditionally these crop remains are considered to be a source of infection, but the infectivity for ToLCNDV of emerging $B$. tabaci adults has not been proven. This particular aspect of virus retention in the whitefly is not only important for efficient management of the short-distance spread of the virus, but it also would be relevant to its long-distance spread. In fact, as part of the regulation of the virus under Commission Implementing Regulation (EU) 2019/2072, the main pathway that was identified for long-distance spread of the virus and of entry in new geographic regions are plants for the planting of susceptible hosts and consist of commodities carrying viruliferous B. tabaci.

Here we compare the parameters of efficiency, minimum acquisition access period (AAP), and inoculation access period (IAP) of ToLCNDV-ES transmission in zucchini and tomato, and we evaluated the retention in the vector. In addition, we determined the viral loads in tomato and zucchini, as well as in B. tabaci, feeding as adults, or emerging from pupae on infected tomato and zucchini, and we compared the infectivity of the emerging adults from both plant species.

\section{Results}

\subsection{ToLCNDV Transmission in Zucchini and Tomato}

The proportions of plants that were infected with ToLCNDV-ES following the introduction of increasing numbers of viruliferous adults $B$. tabaci whiteflies were compared. The transmission efficiencies in tomato and zucchini differed for increasing numbers of viruliferous B. tabaci and plant species. All of the 100 zucchini plants were infected after transferring 2, 5, and $20 \mathrm{~B}$. tabaci per plant, as they all were symptomatic and had detectable ToLCNCV DNA as determined by conventional PCR. When they were tested with single viruliferous B. tabaci, $96 \%$ of zucchini plants showed the typical symptoms and were positive for ToLCNDV. In contrast, single B. tabaci whiteflies or groups of 2 of viruliferous whiteflies did not transmit the virus to any of 100 tomato plants. Feeding tomato plants with groups of 5, 20, and 50 viruliferous B. tabaci resulted in 15, 30, and 100\% of symptomatic and virus positive tomato plants, respectively (Table 1 ).

The efficiency of transmission of $B$. tabaci adults that had fed on infected plants contrasted with that from adults that emerged from pupae that were reared on infected plants. Only 4 out of 20 B. tabaci adults that were collected immediately after emerging from the pupal stages on infected zucchini plant leaves were found to infect virus-free zucchini plantlets in transmission experiments using one adult insect per plant. In contrast, 
no transmission to zucchini was found by 20 individual adults that had emerged from pupae on infected tomato leaves at the same insect/plant rate.

Table 1. Transmission efficiency of ToLCNDV-ES to zucchini and tomato by B. tabaci ${ }^{\text {a }}$.

\begin{tabular}{cccccc}
\hline \multirow{2}{*}{ Plant } & \multicolumn{5}{c}{ Number of Viruliferous B. tabaci } \\
Species & $\mathbf{1}$ & $\mathbf{2}$ & $\mathbf{5}$ & $\mathbf{2 0}$ & $\mathbf{5 0}$ \\
\cline { 2 - 5 } & $96(96)^{\mathrm{b}}$ & $100(100)$ & $100(100)$ & $100(100)$ & Not done \\
Zucchini & $0(0)$ & $0(0)$ & $15(15)$ & $30(34)$ & $100(100)$ \\
Tomato & &
\end{tabular}

${ }^{a}$ B. tabaci whiteflies were allowed a $72 \mathrm{~h}$ virus AAP, and then transferred onto virus-free seedlings for $96 \mathrm{~h}$. Each experiment was conducted on groups of 100 plants. $^{\mathrm{b}}$ percentages of plants expressing ToLCNDV symptoms (percentages of positive plants tested with conventional PCR).

\subsection{Inoculation Access Period (IAP)}

The minimum IAP was estimated using virus-free B. tabaci that was transferred for feeding during $72 \mathrm{~h}$ on ToLCNDV- infected zucchini plants. Next, groups of 20 viruliferous adult $B$. tabaci whiteflies were transferred onto virus-free zucchini and tomato plants. After periods ranging from $5 \mathrm{~min}$ to $24 \mathrm{~h}$, they were removed, and 21 days later, apical leaf samples were removed and tested by conventional PCR. In three independent experiments, viruliferous $B$. tabaci infected $53 \%$ of zucchini plants and $43 \%$ of tomato plants following $5 \mathrm{~min}$ of feeding with viruliferous $B$. tabaci. Inoculation periods of $15 \mathrm{~min}$ were required to infect $90 \%$ of zucchini plants but the proportions of the infected tomato plants were about $50 \%$. Higher proportions of tomato plants were infected after increasing inoculation feeding periods, but never exceeded $80 \%$ of the plants (Table 2.)

Table 2. Inoculation feeding period of the transmission of ToLCNDV by B. tabaci.

\begin{tabular}{|c|c|c|c|c|c|c|c|c|c|}
\hline \multirow{3}{*}{ IAP } & \multicolumn{8}{|c|}{ Host Plant Species } & \multirow[b]{3}{*}{$p$-Value ${ }^{\mathrm{b}}$} \\
\hline & \multirow[b]{2}{*}{ Exp. 1} & \multicolumn{3}{|c|}{ Tomato } & \multicolumn{4}{|c|}{ Zucchini } & \\
\hline & & Exp. 2 & Exp. 3 & Mean \pm S.D. & Exp. 1 & Exp. 2 & Exp. 3 & Mean \pm S.D & \\
\hline $0 \mathrm{~min}$ & $0^{a}$ & 0 & 0 & $0.00 \pm 0.00$ & 0 & 0 & 0 & $0.00 \pm 0.00$ & - \\
\hline $5 \mathrm{~min}$ & 4 & 4 & 5 & $4.33 \pm 0.58$ & 5 & 6 & 5 & $5.33 \pm 0.58$ & 0.101 \\
\hline $15 \min$ & 5 & 4 & 6 & $5.00 \pm 1.00$ & 9 & 10 & 9 & $9.33 \pm 0.58$ & 0.003 \\
\hline $30 \mathrm{~min}$ & 3 & 6 & 5 & $4.67 \pm 1.53$ & 10 & 9 & 10 & $9.67 \pm 0.58$ & 0.006 \\
\hline $60 \mathrm{~min}$ & 7 & 7 & 7 & $7.00 \pm 0.00$ & 10 & 9 & 10 & $9.67 \pm 0.58$ & 0.001 \\
\hline $6 \mathrm{~h}$ & 4 & 5 & 7 & $5.33 \pm 1.53$ & 8 & 10 & 9 & $9.00 \pm 1.00$ & 0.025 \\
\hline $16 \mathrm{~h}$ & 8 & 6 & 8 & $7.33 \pm 1.15$ & 9 & 10 & 10 & $9.67 \pm 0.58$ & 0.035 \\
\hline $24 \mathrm{~h}$ & 6 & 8 & 7 & $7.00 \pm 1.00$ & 10 & 10 & 9 & $9.67 \pm 0.58$ & 0.016 \\
\hline
\end{tabular}

${ }^{a}$ Numbers of plants (total $=10$ ) positive por the virus by PCR, following different feeding periods; ${ }^{\mathrm{b}}$ A two-tailed $t$-test was applied for comparisons of differences between the numbers of infected tomato and zucchini plants. $p$-value $<0.05$ considered as statistically significant; S. D., standard deviation.

\subsection{Acquisition Access Period (AAP)}

The minimum AAP that was required for transmission was determined by allowing groups of 50 virus-free $B$. tabaci whiteflies in clip-cages to feed on ToLCNDV-infected zucchini and tomato plants. After periods of 5, 15, 30, and $60 \mathrm{~min}$, and $6 \mathrm{~h}$, they were transferred to virus-free zucchini plants. After another $48 \mathrm{~h}$, they were removed and 19 days later and plants were analyzed by PCR. No transmission of ToLCNDV into zucchini was observed after five min of acquisition feeding. Limited numbers of zucchini plants got infected after 15 and 30 min of acquisition (20-60\%) from the infected zucchini and tomato plants, and all the plants got infected after $6 \mathrm{~h}$ of acquisition feeding period from both source plant species (Table 3 ). 
Table 3. Acquisition access period of the transmission of ToLCNDV-ES by B. tabaci.

\begin{tabular}{cccccc}
\hline \multirow{2}{*}{ Source Species } & \multicolumn{5}{c}{ AAP (min) } \\
\cline { 2 - 6 } & $\mathbf{5}$ & $\mathbf{1 0}$ & $\mathbf{3 0}$ & $\mathbf{6 0}$ & $\mathbf{3 6 0}$ \\
\hline Zucchini & $0^{\mathrm{a}}$ & 20 & 60 & 80 & 100 \\
Tomato & 0 & 20 & 20 & 40 & 100 \\
\hline a Percentages in groups of 50 target plants (zucchini) positive for ToLCNDV-ES.
\end{tabular}

a Percentages in groups of 50 target plants (zucchini) positive for ToLCNDV-ES.

\subsection{Persistence of Virus Infectivity in B. tabaci Adults}

Virus-free B. tabaci adults were given a $72 \mathrm{~h}$ AAP on ToLCNDV-infected zucchini and then transferred to eggplant, and then as groups of 20 insects were transferred immediately to virus-free zucchini plants. Next, groups of 20 insects were transferred every two days from the eggplants onto virus-free zucchini. For three weeks after transmission, all the zucchini plants were observed for the expression of symptoms and tested for the virus by conventional PCR. It showed that viruliferous $B$. tabaci infected zucchini plants after periods of up to 14 days maintained on eggplant. Most of the insects retained infectivity for two days, which then gradually reduced and was completely lost after 9, 14, and 16 days, in three independent experiments (Table 4).

Table 4. Persistence of infectivity by adults B. tabaci whiteflies.

\begin{tabular}{cccccc}
\hline \multirow{2}{*}{ Days } & \multicolumn{2}{c}{ Number of Plants Infected with ToLCNDV-ES } & \multirow{2}{*}{ Mean \pm S.D. } & Mean $\% \pm$ S.D \\
\cline { 2 - 4 } & Experiment 1 & Experiment 2 & Experiment $\mathbf{3}$ & & \\
\hline $0^{\mathrm{a}}$ & $20^{\mathrm{b}}$ & 18 & 20 & $19.33 \pm 1.15$ & $96.67 \pm 5.77$ \\
2 & 20 & 18 & 20 & $19.33 \pm 1.15$ & $96.67 \pm 5.77$ \\
5 & 20 & 10 & 16 & $15.33 \pm 5.03$ & $76.67 \pm 25.17$ \\
7 & 18 & 8 & 16 & $14.00 \pm 5.29$ & $70.00 \pm 26.46$ \\
9 & 4 & 0 & 6 & $3.33 \pm 3.06$ & $16.67 \pm 15.28$ \\
12 & 4 & 0 & 2 & $2.00 \pm 2.00$ & $10.00 \pm 10.00$ \\
14 & 4 & 0 & 0 & $1.33 \pm 2.31$ & $6.67 \pm 11.55$ \\
16 & 0 & 0 & 0 & $0.00 \pm 0.00$ & $0.00 \pm 0.00$ \\
19 & 0 & 0 & 0 & $0.00 \pm 0.00$ & $0.00 \pm 0.00$ \\
21 & 0 & 0 & $0.00 \pm 0.00$ \\
\hline
\end{tabular}

a Days of B. tabaci transfer after $48 \mathrm{~h} \mathrm{AAP;}{ }^{\mathrm{b}}$ numbers of zucchini plants infected out of 20.

\subsection{ToLCNDV Accumulation in Zucchini, Tomato, and B. tabaci}

The mean relative accumulation of ToLCNDV was $3.08 \times 10^{10}$ in zucchini and $6.25 \times 10^{4}$ in tomato plants. All plants that were infected with ToLCNDV had detectable amounts of virus. The viral loads of 10 infected zucchini plants ranged from $6.11 \times 10^{9}$ to $4.39 \times 10^{11}$, with a mean value of $7.86 \times 10^{10}$. All $50 \mathrm{~B}$. tabaci adults that were collected from these ToLCNDV-infected zucchini plants were positive for the virus with viral loads ranging from $7.64 \times 10^{4}$ to $2.47 \times 10^{10}$, with a mean value of $3.49 \times 10^{9}$. A minimum viral load of $10^{5}$ was found in $98 \%$ of these whiteflies. When leaves containing the immature stages of the vector were removed and dried, emerging adults were collected and the ToLCNDV was determined. From 50 emerging adults, $40(80 \%)$ of those that were tested were positive and $10(20 \%)$ were negative. The positive $B$. tabaci adults had viral loads ranging from $1.82 \times 10^{2}$ to $1.51 \times 10^{7}$. Among the emerging vectors from zucchini leaves, 13 adults had a viral load that was higher than $10^{5}$, which is equivalent to $26 \%$ of all emerging individuals of infected zucchini (Figure 1).

All the tomato plants that were infected with ToLCNDV had detectable amounts of the virus, but the amounts were very variable and ranged from $7.54 \times 10^{1}$ to $1.93 \times 10^{9}$, with a mean value of $8.92 \times 10^{8}$. In contrast to what was observed in the zucchini, approximately $10 \%$ of the $50 \mathrm{~B}$. tabaci adults that were collected from the infected tomato tested negative for ToLCNDV by qPCR. The remaining $90 \%$ of the insects had detectable amounts of virus, ranging from $1.41 \times 10^{1}$ to $2.31 \times 10^{6}$, and $95 \%$ of these positive insects had viral loads 
below $10^{5}$. The Wilcoxon test for the comparison of independent populations comparing the accumulation values of ToLCNDV for adults that were collected from infected zucchini (median relative viral load $9.90 \times 10^{8}$ ) and from tomato (median relative viral load $\left.2.51 \times 10^{3}\right)$ was significantly different $(p<0.05$, with a confidence level of $95.0 \%)$. From 50 emerging adults, $13(26 \%)$ out of the 50 that emerged from the dried leaves of infected tomato tested negative. The positive $B$. tabaci had viral loads ranging from 1.02 to $4.68 \times 10^{2}$ (Figure 1).

\section{Log (relative accumulation of ToLCNDV)}

12

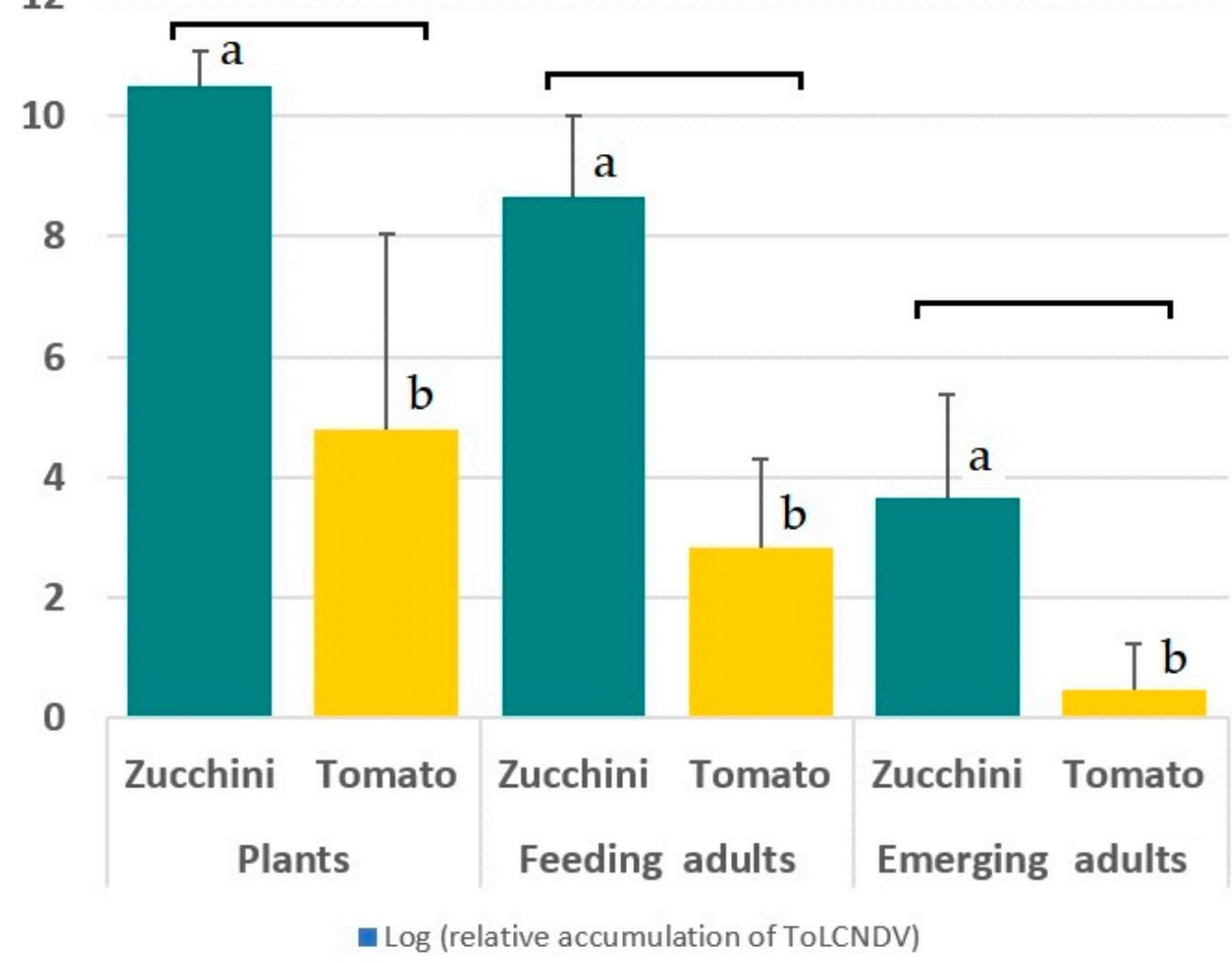

Figure 1. Log-transformed ToLCNDV accumulation in infected zucchini and tomato plants, in B. tabaci adults feeding on infected plants, and in adults emerging from pupae that were collected from dried leaves of infected zucchini and tomato plants. The mean values of 50 replicates in each group; the bars represent S.D. The letters represent the statistical significant difference $(p<0.05)$ using the Wilcoxon test.

\section{Discussion}

The whitefly B. tabaci transmits more than 100 species of viruses to plants. The mode of the transmission is related to the taxonomical status of the viruses, and is characterized as semipersistent (criniviruses, ipomoviruses, and torradoviruses) and persistent (begomoviruses) [17]. These viruses generally differ in the values of the transmission parameters, such as: the probability of viruliferous insects to infect a plant, the time it takes a vector to ingest virus and to inoculated the virus into plants by feeding, and in the time the whiteflies remain infective following acquisition of the virus. In the present paper, we have compared the parameters of transmission of the bipartite begomovirus ToLCNDV-ES by the vector, B. tabaci Med-Q1, in two different crop species, tomato and zucchini.

Single viruliferous B. tabaci adults infected $96 \%$ of zucchini plants and none of 100 tested tomato plants. At least five adults were required to achieve infection in $15 \%$ of tomato (Table 1). The transmission efficiencies that were reported for several other bipartite begomovirus pathosystems in tomato are different, e.g., $45-60 \%$ for tomato leaf curl Gujarat 
virus [18], or $42 \%$ for tomato severe rugose virus (ToSRV), and $8 \%$ for tomato golden vein virus (TGVV) [19]. In contrast, when comparing the IAP and AAP of the transmission of ToLCNDV in zucchini and tomato, they were similar for both host-plant species: 5 and 20 min (Tables 2 and 3), respectively. These values fall within the range of those that were reported for ToLCNDV in bottle gourd, which were estimated to be 10 and $30 \mathrm{~min}$ respectively [20]. They are also similar to other begomoviruses, such as tomato leaf curl virus from Bangalore (ToLCV-Ban4) in tomato where minimum AAP and IAP were $10 \mathrm{~min}$ and $20 \mathrm{~min}$, respectively [21].

A single insect is able to acquire monopartite begomovirus TYLCV and transmit it to tomato plants. The reported minimum AAP and IAP of TYLCV isolates by B. tabaci biotype B (MEAM1) varies from 15 to $60 \mathrm{~min}$ and from 15 to $30 \mathrm{~min}$, respectively [22-24]. Similar values were reported for other monopartite geminiviruses infecting tomato such as TYLCV Sardinia virus (TYLCSV) from Italy [25]. The mean infectivity of infected B. tabaci adults was retained during 7 to 14 days (Table 4). In general, begomoviruses are retained in the vector for nearly of almost its entire life. Adults of MEAM1 B. tabaci that acquired tomato severe rugose virus (ToSRV) during an AAP of $24 \mathrm{~h}$ on infected tomato remained viruliferous for 25 days, the maximum period that the insects survived when kept on cabbage plants that are immune to the virus [26]. Tomato leaf curl Sinaloa virus (TOLSCI) was detected in adults of $B$. tabaci up to nine days [27]. However, the squash leaf curl virus (SLCV) was retained in the insect for 26 days [28].

Thus, the maximum retention of 14 days has been measured after a six-hour acquisition period [29]. The retention values of 20 days have also been reported for Chino del tomato virus (CdTV) and tomato yellow vein streak virus (ToYVSV) [30,31], and life-long retention in the vector was reported for tomato yellow leaf curl Thailand virus (TYLCTHV) [32]. Comparisons of the transmission of ToLCNDV-ES and other begomoviruses should be done with caution. Despite differences in vector species, plant host species, and in the experimental circumstances, the values for IAP, AAP, and the persistence of ToLCNDV-ES were similar to those of monopartite and other bipartite begomoviruses. Transmission efficiencies, however, were different, and in other begomovirus pathosystems, this type of difference has been shown to be associated with feeding habits and preferences on the plant hosts that were used for acquisition and transmission [33-36]. The efficiency is further complicated by differences in the amount and distribution of begomoviruses in the different plant hosts being studied [37]. Also, the presence of selected endosymbionts (ex. Hamiltonella spp.) has been shown to affect the transmission efficiency of begomoviruses [38,39]. Finally, ToLCNDV-ES in Mediterranean countries occurs in cucurbitaceous crops that are potentially co-infected with $B$. tabaci-transmitted cucurbit yellow stunting disorder crinivirus (CYSDV) and cucumber vein yellowing ipomovirus (CVYV) [40]. These semipersistant transmitted viruses have no latent period after ingestion and the retention in the vector lasts from hours to days, depending on the species [41]. There is no evidence of an interference between CYSDV and CVYV in the transmission by B. tabaci [42,43], but the effect of coinfecting plant viruses on vector-transmission has been suggested in other combinations of mixed infections, i.e., of CYSDV and aphid-transmitted watermelon mosaic virus (WMV) [44]. Therefore, the effect of criniviruses and ipomoviruses on the transmission of ToLCNDV-ES requires further investigation.

The efficiency of ToLCNDV-ES transmission by single insects was low in tomato and very high in zucchini. These differences in the inoculation efficiency were used to explain the predominance of different begomoviruses that are acquired at similar rates by the same vector species in the same crop species, such as tomato severe rugose virus (ToSRV) versus tomato golden vein virus (ToSRV) in Brazilian tomato fields [19,45]. But transmission efficiencies may also reflect host plant resistance and the ability of a virus to replicate inside the host plant [46]. The higher the host plants resistance, the lower the transmission rate and the lower is the amount of virus that is detected in the host plant. This has been shown for TYLCV where viral DNA accumulation was shown to be lower in the resistant source plants compared with the susceptible plants [47]. 
ToLCNDV-ES has been found as natural and experimental infections in cucurbit and solanaceous species $[4,8]$. However, relative incidences of the virus are very different among crops in the same agronomic region of the south-east of Spain. Among commercial crops, the percentages of plants that are infected with ToLCNDV varied from $95 \%$ in zucchini, $80 \%$ in melon, $50 \%$ in cucumber, $0 \%$ in watermelon, and $15 \%$ in tomato [8]. Viral loads in tomato that were experimentally infected with ToLCNDV-ES were also reduced when compared with zucchini (Figure 1). This conforms to previously published comparisons of the viral loads of ToLCNDV-ES in zucchini and in tomato [10]. As such, both the natural incidences of ToLCNDV-ES in zucchini and tomato, the viral loads in this paper, and those that were published before suggest that these are in line with the significantly different efficiencies of transmission in both crop species. Since the transmission efficiency in zucchini is almost $100 \%$ for single insects, and because the disease can be fatal in this crop species, control of ToLCNDV in zucchini is a big challenge, and requires efficient physical vector exclusion using greenhouses and careful planning and application of biological and integrated pest management [48,49]. Moreover, the success of these control strategies could change whenever evidence of differences in the ToLCNDV-ES transmission by co-infecting criniviruses or ipomoviruses is obtained, following the future research as suggested above.

Natural incidences of ToLCNDV-ES are lower in commercial tomato crops [8], which is consistent with the reduced transmission efficiency in this host plant (Table 1). However, crop protection against $B$. tabaci and ToLCNDV should also be applied with care in tomato because these plants may often be co-infected with other begomoviruses, such as monopartite TYLCV species [10], which may compromise the interpretation of the observed symptoms.

The present paper established the retention of ToLCNDV in adult vectors to be around between 7 and 14 days, but here we also determined a different aspect of virus retention: we showed that $20 \%$ of adults that emerged from pupae on drying zucchini plant leaves were actually infective. This ratio is comparable to TYLCV in tomato where $28 \%$ of emerging adults were found to be infective [30]. We also established that the amounts of the virus in emerging adults (ranging between approx. $10^{2}$ and $10^{7}$ ), were generally lower that the amounts in the plants (between approx. $10^{9}$ and $10^{11}$ ). Since the $20 \%$ higher virus levels in adults from the dried zucchini leaves were approx. $10^{5}$ or more, this value may well represent the minimum viral load in vectors that is necessary to achieve a successful infection. In comparison, all single adults that were collected from infected zucchini plants had values above $7 \times 10^{4}$, and $96 \%$ of single adults that successfully infected zucchini. In contrast, none of adults emerging from pupae on the infected dried tomato leaves were able to infect zucchini plants, and $95 \%$ of these B. tabaci had viral loads below $10^{5}$.

The efficiency of transmission and the viral loads in adults that were emerging from pupae may explain why biological control using predators of $B$. tabaci eggs and immature stages can significantly reduce the short-distance spread of the virus in greenhouses $[48,49]$. However, it may be also significant in the long-distance control of ToLCNDV-ES, i.e., in the trade and transport of infected plant material, when no B. tabaci adults are spotted, these commodities may contain small-sized immature stages that could well be a source of infection [50]. On the other hand, the infectivity of emerging adults from infected dried plant materials provides evidence that plants that are removed from the crop either during the growing and harvesting stage, or after the crops have finished, should be carefully covered, in sealed boxes, containers, etc., and carefully treated or destroyed, but not exposed or transported as such as that would permit the spread of emerging viruliferous vectors and, consequently, the spread of the virus. So, ToLCNDV-ES management of crops not only should involve hygiene, vector exclusion, and control during the nursery, production, and harvesting stages, but also once the production and harvesting have finished and the plants are removed from the field or the greenhouse, because even as dried materials, they can contain immature vector stages and produce viruliferous emerging insects. 


\section{Materials and Methods}

\subsection{Host Plants, B. tabaci Populations and Virus Isolate}

Experiments were carried out using zucchini (Cucurbita pepo cv. 'Victoria') and tomato (Solanum lycopersicum "Marmande"). A virus-free population of B. tabaci that were originally collected from a commercial eggplant crop (Solanum melongena) in spring of 2012, was reared on eggplant (cv. Crisol) in insect-proof cages in a growth chamber at $25{ }^{\circ} \mathrm{C}$ day and $20{ }^{\circ} \mathrm{C}$ night, with a 16-h photoperiod. This population was identified as the Mediterranean cryptic species subclade Q1 [12]. For the transmission experiments, B. tabaci adults of the same age were obtained by collecting the insects that emerged during a given 24-h period. ToLCNDV-ES that was originally isolated during 2013 from zucchini that were located in a commercial greenhouse from Almeria, Spain, was maintained on zucchini (C. pepo cv. 'Victoria') with B. tabaci, grown in insect cages as described [6]. The plants and B. tabaci whiteflies were analysed by PCR to ensure the presence of ToLCNDV-ES (primers and protocols are described below), and the absence of cucurbit viruses that are transmitted by B. tabaci in Spain, cucurbit yellow stunting disorder virus and cucumber vein yellowing virus, was confirmed by RT-PCR as described [42].

\subsection{Virus Detection and Quantification}

DNA extracts from zucchini and tomato leaf samples were obtained with the DNeasy Plant kit (QIAGEN, Madrid, Spain), whereas the nucleic acid extracts of $B$. tabaci adults were prepared using Chelex 100 [51]. Conventional PCR for ToLCNDV was carried out using the primer pairs A1UP/A3LOW (5'-AGCACAGCCACGGTGAAGAAC-3' $/ 5^{\prime}$ TTTCATCCTTCGACAGAGTTC-3 $\left.{ }^{\prime}\right)$ and B4UP/B4LOW (5'-ATGTAATTGGTGTCTGGAG TCC-3' $/ 5^{\prime}$-TTAACCTGATGTAGGAACGAACG-3') that were designed based on ToLCNDV sequences that are deposited in GenBank KF89146 and KF891467, respectively. These primer pairs amplify parts of the DNA-A and DNA-B components (1260 and $873 \mathrm{bp}$, respectively) [6]. The conventional PCR reagent was Applied Biosystems AmpliTaq DNA Polymerase (ThermoFisher Scientific, Madrid, Spain) which was used as described with an annealing temperature of $55^{\circ} \mathrm{C}$ [6], and determinations were done in an Eppendorf MasterCycler Personal PCR Thermal Cycler (Eppendorf Iberica S.L.U., Madrid, Spain). The viral load in plant extracts was determined by qPCR using TolAup (5'-CATTATTGCACGAATTTCCG$\left.3^{\prime}\right)$ /TolAdown (5'-ATCGTAGCCGACTGTGTCTG-3') primers as described before [10] but using actine specific primers ActineF (5'-GATGGACAAGTCATCACCATTG-3') and ActineL (5'-CTGAGGACAATGTTTCCGTACA-3') that produced $151 \mathrm{bp}$ product from the actin gene (AY594294) for internal control [52]. For quantification of ToLCNDV in B. tabaci DNA extracts, identical primers were used for the detection of the virus, and primers Bemisia-3F (5'-AAGGATCATTGTCGAACTCGA-3') and 65R (5'-CCTGTGTCCCGCGGG$\left.3^{\prime}\right)$ were used as internal controls [43]. The qPCR reagent was qMAXSen ${ }^{\mathrm{TM}}$ Green Dye qPCR Master Mix2x (CANVAX, Cordoba, Spain), and determinations were done in a LightCycler 96 (Roche, Madrid, Spain). The relative ToLCNDV levels were calculated using the $2-\Delta \Delta \mathrm{Ct}$ expression of the Livak method [53], where $\Delta \Delta \mathrm{Ct}$ is the difference between the $\Delta \mathrm{Ct}$ of each sample and the $\Delta \mathrm{Ct}$ of the calibrator sample.

\subsection{Virus Transmission Parameters Using B. tabaci}

For the estimation of the transmission efficiency, newly emerged (0-24 h) B. tabaci adults were allowed to feed on ToLCNDV-ES-infected zucchini plants as single insects or in groups of 2, 5, 20, and 50 insects (selected at random) for a 72-h acquisition access period (AAP) and then transferred onto virus-free zucchini and tomato target plants (three-leaf stage), that were grown in individual insect-proof cages, for virus transmission. A total of three weeks later, the plants were observed for symptoms and tested by conventional PCR. The persistence of the infectivity of adults that were emerging from pupae that were reared on infected plants was determined as follows: the plant leaves with immature stages of B. tabaci were collected from ToLCNDV-infected zucchini and tomato plants and kept at $25{ }^{\circ} \mathrm{C}$ in plastic cages, covered with an insect screen. As the leaves dried out, they were 
continuously inspected and 20 adults that were emerging from the pupae stage from both plant species each, were collected (Figure 2, Videos S1 and S2) and were transferred as single insects in clip-cages onto virus-free zucchini plants (1 clip-cage/plant). After three weeks, the plants were analysed.
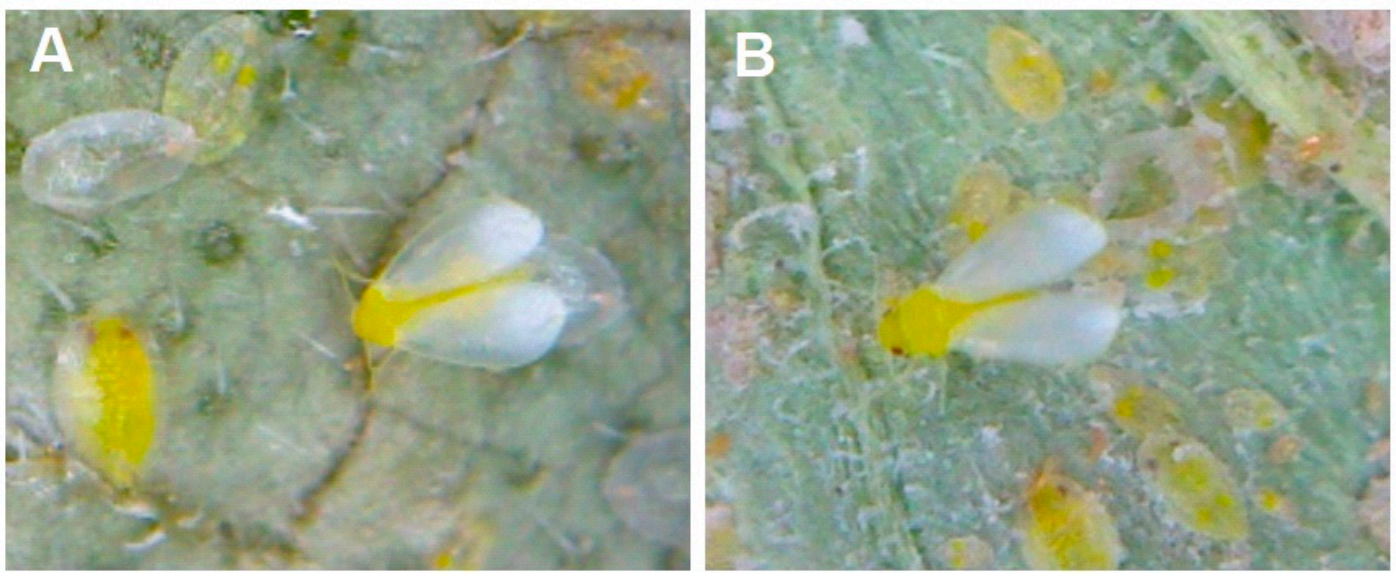

Figure 2. Adult of B. tabaci that were recently emerged from pupae that were developed on ToLCNDVES-infected zucchini (A) and tomato (B) leaves.

The minimum inoculation access period (IAP) was estimated using virus-free $B$. tabaci that were transferred for feeding during $72 \mathrm{~h}$ on ToLCNDV-infected zucchini plants. Next, groups of 20 viruliferous $B$. tabaci adults were transferred onto virus-free zucchini and tomato plants. After periods ranging from $5 \mathrm{~min}$ to $24 \mathrm{~h}$, they were removed, and 21 days later, the apical leaf samples were removed and tested by conventional PCR. A total of three independent experiments were performed.

The minimum AAP that was required for transmission was determined by allowing groups of 50 virus-free $B$. tabaci in clip-cages to feed on ToLCNDV-infected zucchini and tomato plants. After periods of 5, 15, 30, and $60 \mathrm{~min}$, and $6 \mathrm{~h}$, they were transferred to virus-free zucchini plants. After another $48 \mathrm{~h}$, they were removed and 19 days later the plants were analyzed by conventional PCR.

To evaluate the persistence of the infectivity of the vector following acquisition by feeding as adult whiteflies, virus-free $B$. tabaci adults were given a $72 \mathrm{~h}$ AAP on ToLCNDVinfected zucchini and then transferred to eggplant. Groups of 20 insects were transferred immediately to virus-free zucchini plants, and then groups of 20 insects were transferred every two days from the eggplants onto virus-free zucchini. For three weeks after transmission, all zucchini plants were observed for the expression of symptoms and tested for the virus by PCR.

\subsection{ToLCNDV Accumulation in Zucchini, Tomato, and B. tabaci}

To estimate and compare the accumulation of ToLCNDV in the two hosts plant species as well as in the vector, two groups of 50 virus-free $B$. tabaci adults were allowed to feed during 3 weeks on 10 ToLCNDV-infected zucchini and tomato plants in separate insectcages. The insects were removed, and the DNA was extracted from each adult individual, as well as from each tomato and zucchini plant as described above. The qPCR reactions were done as described above. In addition, the viral loads were also determined in adults that were recently emerged from infected plants that were collected as described above. Here, the adults emerging from the pupae stage were collected using a Pasteur pipette and stored at $-20^{\circ} \mathrm{C}$ prior to DNA extraction and qPCR. 
Supplementary Materials: The following are available online at https:/ /www.mdpi.com/article/10 .3390 / plants11030390/s1, Video S1: B. tabaci adult whitefly emerging from pupae on a ToLCNDVinfected zucchini leaf, Video S2: B. tabaci adult whitefly emerging from pupae on a ToLCNDV-infected tomato leaf.

Author Contributions: Conceptualization, D.J.; methodology, D.J. and L.R.; formal analysis, A.S., M.B. and D.J.; investigation, D.J., A.S. and M.B.; resources, D.J.; writing-original draft preparation, D.J. and L.R.; writing-review and editing, D.J. and L.R.; project administration, D.J.; funding acquisition, D.J. All authors have read and agreed to the published version of the manuscript.

Funding: This research was funded by IFAPA and FEDER, grant number AVA2019.015.

Data Availability Statement: Data is contained within the article.

Acknowledgments: We thank Antonia Belmonte for her excellent technical support.

Conflicts of Interest: The authors declare no conflict of interest.

\section{References}

1. Padidam, M.; Beachy, R.N.; Fauquet, C.M. Tomato leaf curl geminivirus from India has a bipartite genome and coat protein is not essential for infectivity. J. Gen. Virol. 1995, 76, 25-35. [CrossRef] [PubMed]

2. Zaidi, S.S.; Martin, D.P.; Amin, I.; Farooq, M.; Mansoor, S. Tomato leaf curl New Delhi virus: A widespread bipartite begomovirus in the territory of monopartite begomoviruses. Mol. Plant Pathol. 2017, 18, 901-911. [CrossRef] [PubMed]

3. Juárez, M.; Tovar, R.; Fiallo-Olivé, E.; Aranda, M.A.; Gosálvez, B.; Castillo, P.; Moriones, E.; Navas-Castillo, J. First detection of Tomato leaf curl New Delhi virus infecting zucchini in Spain. Plant Dis. 2014, 98, 857. [CrossRef] [PubMed]

4. Ruiz, M.L.; Simón, A.; Velasco, L.; García, M.C.; Janssen, D. First report of Tomato leaf curl New Delhi virus infecting tomato in Spain. Plant Dis. 2015, 98, 894. [CrossRef]

5. EPPO (2021) EPPO Global Database Tomato Leaf Curl New Delhi Virus (ToLCNDV). Available online: https://gd.eppo.int/ taxon/TOLCND (accessed on 20 December 2021).

6. Ruiz, L.; Simon, A.; Velasco, L.; Janssen, D. Biological characterization of Tomato leaf curl New Delhi virus from Spain. Plant Pathol. 2017, 66, 376-382. [CrossRef]

7. Fortes, I.M.; Sanchez-Campos, S.; Fiallo-Olive, E.; Diaz-Pendon, J.A.; Navas-Castillo, J.; Moriones, E. A novel strain of tomato leaf curl new delhi virus has spread to the mediterranean basin. Viruses 2016, 8, 307. [CrossRef]

8. Juárez, M.; Rabadan, M.P.; Martinez, L.D.; Tayahi, M.; Grande-Perez, A.; Gomez, P. Natural hosts and genetic diversity of the emerging tomato leaf curl New Delhi virus in Spain. Front. Microbiol. 2019, 10, 140. [CrossRef]

9. Panno, S.; Caruso, A.G.; Troiano, E.; Luigi, M.; Manglli, A.; Vatrano, T.; Iacono, G.; Marchione, S.; Bertin, S.; Tomassoli, L.; et al. Emergence of tomato leaf curl New Delhi virus in Italy: Estimation of incidence and genetic diversity. Plant Pathol. 2019, 68, 601-608. [CrossRef]

10. Simón, A.; Ruiz, L.; Velasco, L.; Janssen, D. Absolute Quantification of Tomato leaf curl New Delhi virus Spain strain, ToLCNDVES: Virus Accumulation in a Host-Specific Manner. Plant Dis 2018, 102, 165-171. [CrossRef]

11. Kil, E.-J.; Vo, T.T.B.; Fadhila, C.; Ho, P.T.; Lal, A.; Troiano, E.; Parrella, G.; Lee, S. Seed Transmission of Tomato Leaf Curl New Delhi Virus from Zucchini Squash in Italy. Plants 2020, 9, 563. [CrossRef]

12. Janssen, D.; Simon, A.; Crespo, O.; Ruiz, L. Genetic population structure of Bemisia tabaci in Spain associated with Tomato leaf curl New Delhi virus. Plant Protect. Sci. 2017, 53, 25-31. [CrossRef]

13. Bertin, S.; Luigi, M.; Parrella, G.; Giorgini, M.; Davino, S.; Tomassoli, L. Survey of the distribution of Bemisia tabaci (Hemiptera: Aleyrodidae) in Lazio region (Central Italy): A threat for the northward expansion of Tomato leaf curl New Delhi virus (Begomovirus: Geminiviridae) infection. Phytoparasitica 2018, 46, 171-182. [CrossRef]

14. Moriones, E.; Praveen, S.; Chakraborty, S. Tomato leaf curl New Delhi Virus: An emerging virus complex threatening vegetable and fiber crops. Viruses 2017, 9, 264. [CrossRef] [PubMed]

15. Ghosh, S.; Ghanim, M. Factors Determining Transmission of Persistent Viruses by Bemisia tabaci and Emergence of New VirusVector Relationships. Viruses 2021, 13, 1808. [CrossRef] [PubMed]

16. Rubinstein, G.; Czosnek, H. Long-term association of tomato yellow leaf curl virus with its whitefly vector Bemisia tabaci: Effect on the insect transmission capacity, longevity and fecundity. J. Gen. Virol. 1997, 78, 2683-2689. [CrossRef]

17. Navas-Castillo, J.; Fiallo-Olivé, E.; Sánchez-Campos, S. Emerging Virus Diseases Transmitted by Whiteflies. Annu Rev. Phytopathol 2011, 49, 219-248. [CrossRef]

18. Chakraborty, S.; Pandey, P.K.; Banerjee, M.K.; Kalloo, G.; Fauquet, C.M. Tomato leaf curl Gujarat virus, a New Begomovirus Species Causing a Severe Leaf Curl Disease of Tomato in Varanasi, India. Phytopathology 2003, 93, 1485-1495. [CrossRef]

19. Macedo, M.A.; Michereff Filho, M.; Navas-Castillo, J.; Inoue-Nagata, A.K. Host range and whitefly transmission efficiency of Tomato severe rugose virus and tomato golden vein virus in tomato plants. Trop. Plant Pathol. 2015, 40, 405-409. [CrossRef] 
20. Rajeshwari, R.; Reddy, M.K. Biological characterisation of Tomato Leaf Curl New Delhi Virus infecting bottle gourd (Lagenaria siceraria) from Karnataka. Mysore J. Agric. Sci. 2014, 48, 387-393. Available online: https://www.cabdirect.org/cabdirect/ abstract/20153302183 (accessed on 20 December 2021).

21. Muniyappa, V.; Venkatesh, H.M.; Ramappa, H.K.; Kulkarni, R.S.; Zeidan, M.; Tarba, C.Y.; Ghanim, M.; Czosnek, H. Tomato leaf curl virus from Bangalore (ToLCV-Ban4): Sequence comparison with Indian ToLCV isolates, detecvtion in plants and insects, and vector relationships. Arch. Virol. 2000, 145, 1583-1598. [CrossRef]

22. Cohen, S.; Harpaz, I. Periodic, rather than continual acquisition of a new tomato virus by its vector, the tobacco whitefly (Bemisia tabaci Gennadius). Entomol. Exp. Appl. 1964, 7, 155-166. [CrossRef]

23. Mansour, A.; Al-Musa, A. Tomato yellow leaf curl virus: Host range and virus-vector relationships. Plant Pathol. 1992, $41,122-125$. [CrossRef]

24. Mehta, P.; Wyman, J.A.; Nakhla, M.K.; Maxwell, S.P. Transmission of tomato yellow leaf curl geminivirus by Bemisia tabaci (Homoptera: Aleyrodidae). J. Econ. Entomol. 1994, 87, 1291-1297. [CrossRef]

25. Caciagli, P.; Bosco, D. Quantitation over time of tomato yellow leaf curl geminivirus DNA in its whitefly vector. Phytopathology 1997, 87, 610-613. [CrossRef]

26. Toloy, R.S.; Mituti, T.; Freitas, D.M.S.; Maluta, N.K.P.; Silva, T.N.Z.; Lopes, J.R.S.; Fereres, A.; Marques, J.A. Features of the relationship between Tomato severe rugose begomovirus and Bemisa tabaci MEAM1 reveal that the virus is acquired during a probe lasting only one minute. Eur. J. Plant Pathol. 2018, 151, 541-547. [CrossRef]

27. Idris, A.M.; Brown, J.K. Sinaloa tomato leaf curl virus geminivirus: Biological and molecular evidence for a new sub-group III virus. Phytopathology 1998, 88, 648-657. [CrossRef]

28. Cohen, S.; Duffus, J.E.; Larsen, R.C.; Liu, H.; Flock, R.A. Purification, serology and vector relationships of squash leaf curl virus, a whitefly-transmitted geminivirus. Phytopathology 1983, 73, 1669-1673. [CrossRef]

29. Cohen, S.; Nitzany, F.E. Transmission and host range of Tomato yellow leaf curl virus. Phytopathology 1966, 56, $1127-1131$.

30. Costa, A.S.; Bennett, C.W. Whitefly-transmitted mosaic of Euphorbia prunifolia. Phytopathology 1950, 40, $266-283$.

31. Firmino, A.C.; Yuki, V.A.; Moreira, A.G.; Rezende, J.A.M. Tomato yellow vein streak virus: Relationship with Bemisia tabaci biotype B and host range. Sci. Agric. 2009, 66, 793-799. [CrossRef]

32. Weng, S.H.; Tsai, W.S.; Kenyon, L.; Tsai, C.W. Different transmission efficiencies may drive displacement of tomato begomoviruses in the fields in Taiwan. Ann. Appl. Biol. 2015, 166, 321-330. [CrossRef]

33. Bedford, I.D.; Briddon, R.W.; Brown, J.K.; Rosell, R.C.; Markham, P.G. Geminivirus transmission and biological characterization of whitefly Bemisia tabaci biotypes from different geographic regions. Ann. Appl. Biol. 1994, 125, 311-325. [CrossRef]

34. Jiang, Y.X.; de Blas, C.; Barrios, L.; Fereres, A. Correlation between whitefly (Homoptera: Aleyrodidae) feeding behavior and transmission of tomato yellow leaf curl virus. Ann. Entomol. Soc. Am. 2000, 93, 573-579. [CrossRef]

35. Jiang, Y.X.; de Blas, C.; Bedford, I.D.; Nombela, G.; Muñiz, M. Effect of Bemisia tabaci biotype in the transmission of Tomato yellow leaf curl Sardinia virus (TYLCSV-ES) between tomato and common weeds. Span. J. Agric. Res. 2004, 2, 115-119. [CrossRef]

36. Sanchez-Campos, S.; Navas-Castillo, J.; Camero, R.; Soria, C.; Diaz, J.A.; Moriones, E. Displacement of tomato yellow leaf curl virus (TYLCV)-Sr by TYLCV-Is in tomato epidemics in Spain. Phytopathology 1999, 89, 1038-1043. [CrossRef]

37. Azzam, O.; Frazer, J.; de La Rosa, D.; Beaver, J.S.; Alquist, P.; Maxwell, D.P. Transmission and efficient ssDNA accumulation of bean golden mosaic geminivirus require functional coat protein. Virology 1994, 204, 289-296. [CrossRef]

38. Gottlieb, Y.; Zchori-Fein, E.; Mozes-Daube, N.; Kontsedalov, S.; Skaljac, M.; Brumin, M.; Sobol, I.; Czosnek, H.; Vavre, F.; Fleury, F.; et al. The transmission efficiency of tomato yellow leaf curl virus by the whitefly Bemisia tabaci is correlated with the presence of a specific symbiotic bacterium species. J. Virol. 2010, 84, 9310-9317. [CrossRef]

39. Su, Q.; Pan, H.; Liu, B.; Chu, D.; Xie, W.; Wu, Q.; Wang, S.; Xu, B.; Zhang, Y. Insect symbiont facilitates vector acquisition, retention, and transmission of plant virus. Sci. Rep. 2013,3, 1367. [CrossRef]

40. Velasco, L.; Ruiz, L.; Galipienso, L.; Rubio, L.; Janssen, D. A Historical Account of Viruses in Intensive Horticultural Crops in the Spanish Mediterranean Arc: New Challenges for a Sustainable Agriculture. Agronomy 2020, 10, 860. [CrossRef]

41. Fiallo-Olivé, E.; Pan, L.L.; Liu, S.S.; Navas-Castillo, J. Transmission of Begomoviruses and Other Whitefly-Borne Viruses: Dependence on the Vector Species. Phytopathology 2020, 110, 10-17. [CrossRef] [PubMed]

42. Ruiz, L.; Janssen, D.; Martin, G.; Velasco, L.; Segundo, E.; Cuadrado, I.M. Analysis of the temporal and spatial disease progress of Bemisia tabaci-transmitted Cucurbit yellow stunting disorder virus and Cucumber vein yellowing virus in cucumber. Plant Pathol. 2006, 55, 264-275. [CrossRef]

43. Gil-Salas, F.M.; Morris, J.; Colyer, A.; Budge, G.; Boonham, N.; Cuadrado, I.M.; Janssen, D. Development of real-time RT-PCR assays for the detection of Cucumber vein yellowing virus (CVYV) and Cucurbit yellow stunting disorder virus (CYSDV) in the whitefly vector Bemisia tabaci. J. Virol. Meth. 2007, 146, 45-51. [CrossRef] [PubMed]

44. Domingo-Calap, M.L.; Moreno, A.B.; Díaz Pendón, J.A.; Moreno, A.; Fereres, A.; López-Moya, J.J. Assessing the Impact on Virus Transmission and Insect Vector Behavior of a Viral Mixed Infection in Melon. Phytopathology 2020, 110, 174-186. [CrossRef] [PubMed]

45. Fernandes, F.R.; Albuquerque, L.C.; Giordano, L.B.; Boiteux, L.C.; Ávila, A.C.; Inoue-Nagata, A.K. Diversity and prevalence of Brazilian bipartite begomovirus species associated to tomatoes. Virus Genes 2008, 36, 251-258. [CrossRef] [PubMed]

46. Martin, R.R.; Keese, P.K.; Young, M.J.; Waterhouse, P.M.; Gerlach, W.L. Evolution and molecular biology of luteoviruses. Annu. Rev. Phytopathol. 1990, 28, 341-363. [CrossRef] 
47. Lapidot, M.; Friedmann, M.; Pilowsky, M.; Ben-Joseph, R.; Cohen, S. Effect of Host Plant Resistance to Tomato yellow leaf curl virus (TYLCV) on Virus Acquisition and Transmission by Its Whitefly Vector. Phytopathology 2001, 91, 1209-1213. [CrossRef]

48. Tellez, M.M.; Simon, A.; Rodriguez, E.; Janssen, D. Control of Tomato leaf curl New Delhi virus in zucchini using the predatory mite Amblyseius swirskii. Biol. Control 2017, 114, 106-113. [CrossRef]

49. Rodríguez, E.; Téllez, M.M.; Janssen, D. Whitefly control strategies against tomato leaf curl New Delhi virus in greenhouse zucchini. Int. J. Environ. Res. Public Health 2019, 16, 2673. [CrossRef]

50. Pasquali, S.; Gilioli, G.; Janssen, D.; Winter, S. Optimal strategies for interception, detection, and eradication in plant biosecurity. Risk Anal. 2015, 35, 1663-1673. [CrossRef]

51. Walsh, P.S.; Metzger, A.; Higuchi, R. Chelex 100 as a medium for simple extraction of DNA for PCR-based typing from forensic material. Biotechniques 1991, 10, 506-513. [CrossRef]

52. Aguilar, E.; Del Toro, F.J.; Canto, T.; Tenllado, F. Identification of MAPKs as signal transduction components required for the cell death response during compatible infection by the synergistic pair Potato virus X-Potato virus Y. Virology 2017, 509, 178-184. [CrossRef] [PubMed]

53. Livak, K.J.; Schmittgen, T.D. Analysis of relative gene expression data using real-time quantitative PCR and the 2(-Delta Delta Ct) method. Methods 2001, 25, 402-408. [CrossRef] [PubMed] 